\title{
CRITERIA USED IN THE LFS TO IDENTIFY \\ THE POPULATION'S ECONOMIC ACTIVITY STATUS VS. THE RESPONDENTS' SUBJECTIVE VIEWS: IMPLICATIONS FOR UNEMPLOYMENT RESEARCH ${ }^{*}$
}

\author{
Włodzimierz Kołodziejczak \\ Poznań University of Life Sciences, Poznań, Poland \\ e-mail: kolodziejczak@up.poznan.pl \\ ORCID: 0000-0001-7315-6717 \\ (C) 2018 Włodzimierz Kołodziejczak \\ This is an open access article distributed under the Creative Commons Attribution-NonCommercial- \\ -NoDerivs license (http://creativecommons.org/licenses/by-nc-nd/3.0/)
}

DOI: 10.15611/eada.2018.3.07

JEL Classification: J21, J64

\begin{abstract}
In the Labour Force Survey (LFS) the interviewees are considered as employed, unemployed or professionally inactive based on "objective" criteria defined in the survey's methodological assumptions (e.g. the fact that a person is seeking employment, waiting to start work or worked at least one hour in the reference week). In use since 1992, the above approach allows the classification to be unaffected by the respondents' subjective feelings. Since 2006, LFS respondents have been also allowed to identify their economic activity status by themselves. The objective of this paper is to indicate and attempt to explain the differences between the results based on the identification of economic activity statuses as per the criteria adopted by the Central Statistical Office and the LFS respondents' own assessment of their economic activity status. This paper assessed the rationale behind each approach and the implications thereof for the procedure and results of unemployment surveys from a static and dynamic perspective.
\end{abstract}

Keywords: Labour Force Survey (LFS), unemployment, economic activity, inflow/outflow analysis.

\section{Introduction}

Public statistics are an important and valuable source of information on socioeconomic realities. However, just as with every human invention, the methods for data acquisition and pattern identification are not perfect. It could be claimed that the more sophisticated and complicated the methods, the greater the distance between

* The paper is funded by the National Science Centre within the MINIATURA research project No. NCN DEC-2017/01/X/HS4/00565, entitled "Determinants of economic activity of the rural population in Poland. Opportunities to reduce hidden unemployment in agriculture" (Determinanty aktywności ekonomicznej ludności wiejskiej w Polsce. Możliwości redukcji bezrobocia ukrytego w rolnictwie). 
the survey results and the perceptions of an "average observer" of socio-economic realities. Obviously this is not an argument against the concept of using sophisticated statistical methods. Public statistics deal with a world full of restrictions affecting data availability and the economic viability of data acquisition. There are also legal regulations that may prohibit the collection or delivery of data. Thus, fully aware of the existing limitations, the researchers collect, process and present data to provide the most accurate (though obviously imperfect) picture possible of the realities ${ }^{1}$.

One of the research areas of public statistics is the population's activity and status in the labour market. In Poland the relevant surveys are conducted by the Central Statistical Office as a part of the EU Labour Force Survey (LFS). The interviewees are considered as employed, unemployed or professionally inactive based on "objective" criteria defined in the survey's methodological assumptions (e.g. the fact that a person is seeking employment, waiting to start work or worked at least one hour in the reference week). In use in Poland since 1992, the above approach allows the classification to be unaffected by the respondents' subjective feelings. Since 2006, LFS respondents have also been allowed to identify their economic activity status by themselves (subjectively). The "objective" and "subjective" classifications often provide different results which is a reason to consider the causes and consequences of that finding.

Therefore the objective of this paper is to indicate and attempt to explain the differences between the results based on the identification of economic activity status as per the criteria adopted by the Central Statistical Office, and the LFS respondents' own assessment of their economic activity status. To attain the defined objective, a set of the basic indicators of the population's labour market status was established: labour force participation rate, employment rate, and unemployment rate, as calculated by the Polish Central Statistical Office based on weighted data or based on individual non-weighted data in accordance with the two following approaches: 1) as per the criteria for the identification of the labour market status used by the Central Statistical Office (the "objective" approach) or 2) using the status indicated by the LFS respondents themselves (the "subjective" approach). Later in this paper one will find the results of a study covering the basic characteristics of the population's economic activity and the inflow/outflow rates (transitions between labour market statuses), as well as an estimation of the equilibrium unemployment rate based on the CEPR method [Unemployment... 1995]. There were also used the calculated rates of inflow and outflow to/from specific activity statuses and the estimations of the equilibrium unemployment rate based on the labour market inflow/outflow analysis (IOA) and the CEPR formula [Unemployment... 1995]. The

${ }^{1}$ This can result in a misperception of the essence of economic developments, making it difficult to put them in the context of economic theory. For instance, if a complicated method is used to calculate the inflation rate and GDP, it could be impossible to explain other developments (e.g. changes in debt or unemployment levels) based on proven concepts. However, it becomes easy once the data is "cleaned" by removing weights and other modifications (e.g. hedonism indexes). More: [Masterson 2011]. 
results of quarterly calculations were averaged over 2016. The empirical part of this study is based on a dataset from the Labour Force Survey conducted through the four quarters of 2016, including: 1) the values of the labour force participation rate, employment rate and unemployment rate calculated as part of the LFS by the Central Statistical Office based on weighted data; 2) own estimations of the above rates based on individual non-weighted 2016 LFS quarterly data; 3) own estimation of inflow and outflow rates to/from specific activity statuses; and estimations of the equilibrium unemployment rate. The theoretical part relies on relevant literature and on information retrieved from the EU-LFS and Central Statistical Office websites.

\section{Methodological aspects and their practical implications}

\subsection{Basic terms and their meaning}

The topic discussed in this paper is the population's economic activity, one of the socio-economic aspects described with public statistics data. Even though the Labour Force Survey (LFS) has been conducted for many years by the statistical offices of European countries in accordance with the guidelines set out in the Council Regulation (EC) No. 577/98 on the organization of a labour force sample survey in the Community, the essence of economic activity is defined neither in websites nor in the publications of EUROSTAT and of the competent national statistical offices (the available definitions describe the economically active population rather than economic activity itself). An attempt to provide such a definition was made by Kołodziejczak and Wysocki [2007], according to whom: the economic activity is a natural characteristic of a population related to the existence of humans and their households. It plays essentially the same role as hunting and gathering for primitive societies. For an individual or a household, the objective of economic activity is to provide essential means for survival and social living. The above definition implies that if the essence of economic activity is related to natural human compulsions, then the subjective perception of one's own economic activity is at least equally important as the indicators defined by statistical offices based on general criteria.

Already at this quite general level, many methodological problems may be expected to arise which hinder research efforts and obscure the researcher's view of the developments taking place in the economically active population. As regards the LFS, the first source of confusion may be the quite flexible and imprecise translation of basic terms. Even the differences between the names of the population surveyed become problematic. The Polish Central Statistical Office uses the term "economically active population" in BAEL research (Polish LFS) as a synonym for the entire population at the age of 15 and above (it includes the employed, unemployed and economically inactive population). Meanwhile, the EU Labour Force Survey (EU-LFS) for the same sense uses the concept "active and inactive population 15 years and above." Contrary to Poland, according to the EU-LFS, the 
"economically active population" is equivalent to the labour force which includes only employed and unemployed persons.

Another problem encountered in the past were the heterogeneous criteria for the identification of the population's economic activity in various countries covered by the LFS. Kabaj [2003] paid specific attention to the employment criterion: in Poland, one hour a week was enough to be considered as an employee while in other countries that level was set higher, reaching 20 hours in some cases. Efforts were made to unify the identification criteria and survey methodologies over subsequent years. Today, coherent criteria are applicable to the identification of the population's economic activity, as provided in the guidelines set out in the European Union Labour Force Survey Methods and definitions 2001. For instance, the one-hour criterion is currently valid in all the countries covered by the survey.

While the structuring and unification of the EU-LFS methodology between the countries resulted in improving data quality and comparability across European countries, it failed to eliminate all difficulties and ambiguities.

\subsection{EU-LFS methodology}

To ensure the comparability of the statistical results across countries and along time, the EU-LFS uses the same concepts and definitions, follows International Labour Organization guidelines, uses common classifications (NACE, ISCO, ISCED, NUTS) and records the same set of characteristics in each country (Figure 1). Only private households are covered by the survey; collective living quarters are excluded. The population surveyed is characterized according to demographic features, place of residence and household composition. Afterwards, persons who meet the criteria to be considered as the "active and inactive population 15 years and above" are selected. This population is further divided into sub-groups by education level; afterwards, the following groups are established: the active population (employed and unemployed) and the inactive population (unemployed who do not seek employment). The active population includes all employed and unemployed individuals. The inactive population includes all individuals who can be considered neither employed nor unemployed ${ }^{2}$. The LFS diagram is shown in Figure 2. According to the LFS methodology applied by the Central Statistical Office, the "employed" category includes all persons aged 15 and above who during the reference week [Economic activity... 2016]:

\footnotetext{
${ }^{2}$ There are two ways of measuring the employment or unemployment levels: based on the register of persons employed in the national economy and of unemployed persons who apply for or receive unemployment benefits; or based on labour force surveys which use an accepted definition of unemployment [Kwiatkowski 2002; Mankiw, Taylor 2009]. In Poland, both methods are used in statistical surveys; the number of employed or unemployed is estimated either by registering new employment and dismissals, or by using the Labour Force Survey (LFS) conducted with a representative population sample aged 15 and above. Households within collective living quarters (e.g. boarding houses, penal institutions) and persons resident abroad are not covered by the LFS.
} 
- performed for at least one hour any work generating pay or income, i.e. were employed as employees, worked on their own (or leased) agricultural farm, or conducted their own economic activity outside agriculture, assisted (without pay) in work on family agricultural farm or in conducting family economic activity outside agriculture,

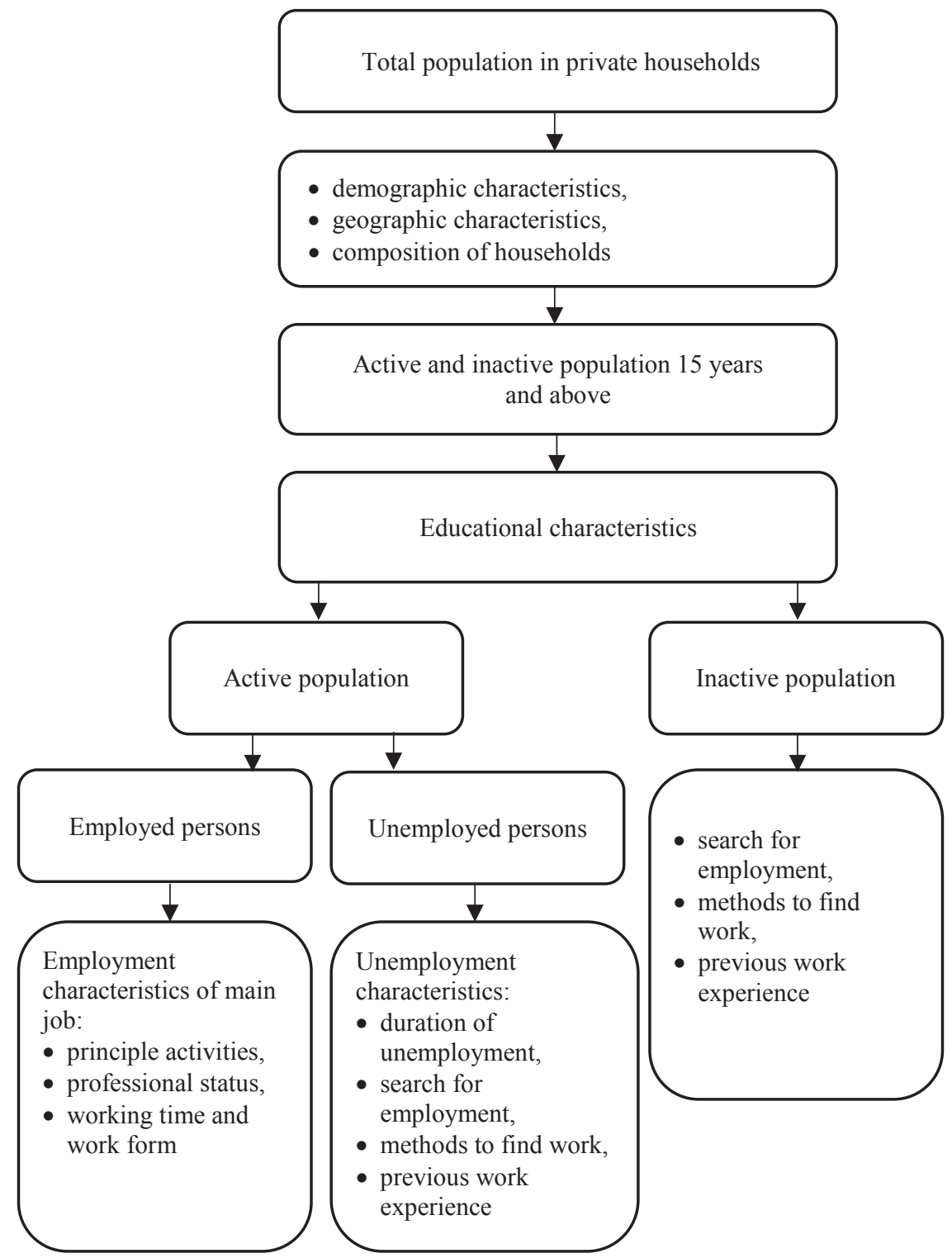

Fig. 1. Typology to classify the statistical information (variables) of the EU-LFS

Source: [http://ec.europa.eu/eurostat/web/lfs/methodology/main-concepts]. 


\footnotetext{
Person 15 old years or above living in a private household

Person did any work for pay or profit during the reference week

Person was not working but had a job or business with absence in the reference week

\section{Unpaid family workers}

Person, 15-74 years old, was not seeking employment because a job which would start within 3 months had already been found

Person, 15-74 years old, was seeking employment
}

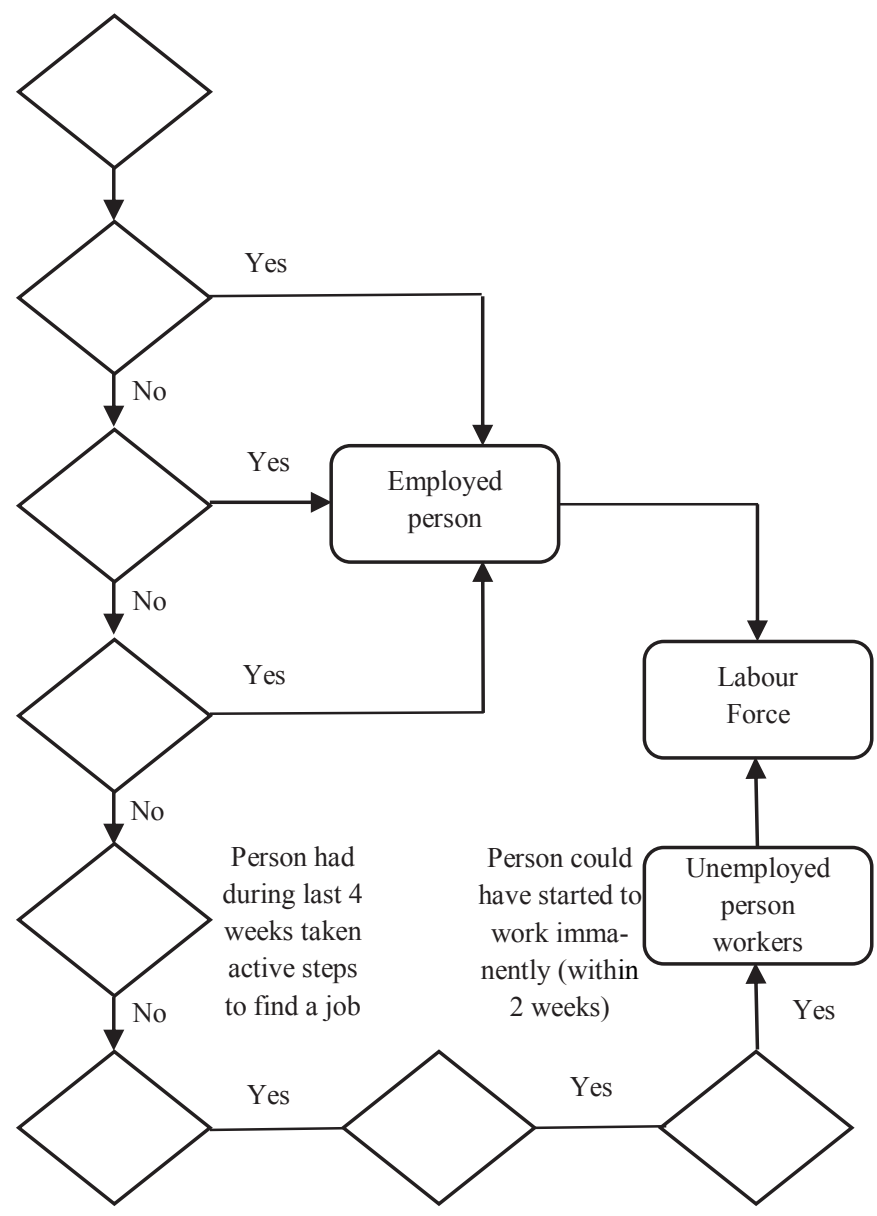

Fig. 2. Labour force classification in the EU-LFS

Source: [http://ec.europa.eu/eurostat/statistics-explained/index.php/EU_labour_force_survey_-_methodology].

- had work but did not perform it:

- due to sickness, maternity leave, parental leave or vacation,

- due to other reasons, but the break in employment,

- did not exceed 3 months,

- exceeded 3 months, but these persons worked as employees and during that period received at least $50 \%$ of the hitherto remuneration (since the first quarter of 2006).

Among the employed are also included apprentices who entered into occupational training or occupational preparation contract with a private or public employer, if they received remuneration. 
To be considered as unemployed, the interviewees must meet all of the following conditions:

- were not employed in the reference week,

- were actively looking for work, i.e. for over 4 weeks had been involved in concrete actions aimed at finding a job,

- were available to take up work within two weeks after the reference week.

Persons who were not seeking work because they had already found a job and were only waiting to start work within the period no longer than 3 months and they were available for this job (until the end of 2003 the ability to take a job was not taken into consideration) are also included in the category of the unemployed.

The active population includes all employed and unemployed individuals. The inactive population includes all individuals who can be considered neither employed nor unemployed. A weight is assigned to each of the interviewees to reflect how he/she is representative of the composition of the sample and of the demographic characteristics of the area surveyed. The weights allow to maintain the representativeness of the sample despite its non-proportional composition. Overrepresented and under-represented areas are assigned with correspondingly smaller and greater weights [Economic activity... 2016]. In the survey, weights assigned to individuals reflect their relationship with the entire sample at national and regional (voivodship) level. However, they are not appropriate for the subsequent disaggregation into smaller territorial units and specific characteristics of the population at voivodship level. Therefore, to assess the population's flows between economic activity statuses and the relationship between a population's characteristics and the changes to its labour market status, it is necessary to rely on non-weighted data and, as a consequence, to consider the results as rough indications rather than exact measurements of trends or evolution lines.

Additionally, since 2006 the interviewees covered by the LFS have been indicating their own economic activity status [Kołodziejczak, Wysocki 2015]. The results of both identification methods often considerably differ from each other. Note also that the results based on the respondents' own subjective views are not included in the periodic LFS reports.

\subsection{The method of estimating the equilibrium unemployment}

To properly understand the example presented in the empirical part, it is necessary to show the method for the calculation and interpretation of the equilibrium unemployment rate and of the flow rates between employment, unemployment and inactivity. The internal structure of the labour force is continually changing while the population keeps flowing between three basic possible statuses of economic activity: employment $(E)$, unemployment $(U)$ and inactivity $(I)$ as the individuals change their position in the labour market. The methods for analysing these changes and their determinants include the Inflow/Outflow Analysis (IOA). This is based 
on the assumption that the analysis of previous changes to the individuals' position in the labour market allows to predict the future evolution of their market position (i.e. to predict whether an individual's status will change or remain as is). As a consequence, discovering the structure of flows between specific activity status allows to deduce whether the individuals grouped by selected characteristics will find (or keep) a job, or are at risk of unemployment or deactivation [Socha, Sztanderska 2002]. In stable conditions, the inflow into $\left(I_{u}\right)$ and outflow from $\left(O_{u}\right)$ unemployment are equal. Therefore, the unemployment rate may be expressed as the ratio of inflow into unemployment to labour force multiplied by the unemployment period [Socha, Sztanderska 2002].

With this approach, it is possible to define and calculate the following, without limitation:

- the ratio of inflow into unemployment to labour force:

$$
i_{u}=\frac{I_{u}}{U+E}
$$

with: $i_{u}$ - ratio of inflow into unemployment to labour force, $I_{u}$ - inflow into unemployment, $U$ - number of unemployed, $E$ - number of employed;

- the unemployment outflow rate:

$$
o_{u}=\frac{O_{u}}{U}
$$

with: $o_{u}$ - unemployment outflow rate, $O_{u}$ - outflow from unemployment, $U-$ number of unemployed.

The analysis of the flow rates and their trend over time allows to determine the fluidity of labour force (and other indicators). The higher the flow rates, the greater the fluidity (mobility) of the economically active population. Low flow rates indicate the importance of structural factors for labour market developments. Usually, the increasing levels of flow rates suggest a decline in the importance of structural factors (but are not an explicit indication of it because in some cases, structural factors may cause an increase in flow rates) [Socha, Sztanderska 2002; Kołodziejczak, Wysocki 2013].

The information on the size and structure of flows allows to estimate the equilibrium unemployment with a method developed by the Center for Economics Policy Research (CEPR) [Unemployment 1995] $]^{3}$ The CEPR method consists in determining the equilibrium unemployment rate as follows [Socha, Sztanderska 2002]:

${ }^{3}$ Depending on the applied method estimating equilibrium unemployment they may be determined for the entire economy, or for individual groups of the population distinguished based on selected characteristics. Models based on the Philips Curve theory or on the hypothesis of rational expectations and neutrality of money, e.g. NAIRU (Non-Accelerating Inflation Rate of Unemployment) and NAWRU 


$$
u^{*}=\frac{s+z}{s+h+n}
$$

with: $\quad u^{*}$ - equilibrium unemployment rate, $s=(E U+E N) / E$ - rate of outflow from employment (to unemployment and inactivity), $h=U E / U$ - unemploymentto-employment flow rate, $z=(N U-U N-E N) /(E+U)$ - demographic component of unemployment, $n$ - percentage changes of labour force over the reference period,

where: $E$ - number of employed at the beginning of the reference period, $U$-number of unemployed at the beginning of the reference period, $E U$ - employmentto-unemployment flow in the reference period (number of individuals who moved from employment to unemployment), $E N$ - employment-to-inactivity flow, $N U$ - inactivity-to-unemployment flow, $U N$ - unemployment-toinactivity flow, $U E$ - unemployment-to-employment flow.

If $u^{*}>u$, real unemployment $(u)$ is likely to increase as it has not yet reached the level resulting from the impact of the labour market's structural factors (labour market mismatches); if $u^{*}<u$, real unemployment is higher than would result from structural factors, and the difference may be roughly equated to unemployment caused by the excessively slow economic growth (which means $u$ is likely to become close to $u^{*}$ in line with the recovery of the market for goods and services) [Kołodziejczak, Wysocki 2013] $]^{4}$.

\section{Empirical study: differences between the approaches; interpreting the results}

The indicators calculated for the population aged 15 and above based on weighted data and on the classification of statuses compliant with the LFS methodology were compared to those based on non-weighted data and on the same classification criteria, and to those based on non-weighted data and on the LFS respondents' subjective classification. Each of these approaches provides a different picture of the population surveyed and indicates different problem areas. This is a reflection of two methodological problems with:

\footnotetext{
(Non-Accelerating Wage Rate of Unemployment) use market variables and their application is limited generally to aggregate data at the level of whole economies [Socha, Wojciechowski 2004]. Methods based on the analysis of changes in the behaviour of individuals on the labour market make it possible to analyse separately groups of the population differing in socio-economic characteristics. The most important of these include the method proposed by the Center for Economics Policy Research (CEPR) [Unemployment... 1995], the Gärtner method [1997] and the method proposed by Darby, Haltiwanger and Plant [1986].

${ }^{4}$ Note that these are simplifying assumptions. The interpretation of results based thereon must take economic and social aspects into consideration.
} 
1) the usefulness and appropriateness of results based on non-weighted data compared to those based on weighted data;

2) the magnitude and causes of the differences between the values of characteristics based on LFS-compliant criteria for the identification of labour market statuses and those based on statuses indicated by each of the respondents.

Table 1 shows the indicators of the population's status and position in the labour market. In addition to the characteristics usually included in the LFS reports (i.e. labour force participation rate, employment rate and unemployment rate), it also presents the following flow rates assessed using the IOA method: employment-tounemployment-and-inactivity; unemployment-to-employment; and employmentand-inactivity-to-unemployment. The table also includes the average duration of the search for employment (though not directly comparable), as specified in the LFS reports, and the average duration of previous unemployment periods estimated using the LFS method.

As can be noticed, in all the groups surveyed, the employment rates specified by the Central Statistical Office based on the LFS were higher than those based on nonweighted data. This could be explained by the imperfection of non-weighted data; note also that the weighted data is useful only up to a quite general disaggregation level used in the LFS. Further disaggregation, though valuable in terms of the information it provides, makes it necessary for the researcher to rely on non-weighted data, being fully aware if its imperfection and of the imprecision of its results 5 .

The lowest employment rates result from calculations based on "subjective" data (Table 1). This suggests a strong mismatch between the official LFS criteria for the identification of labour market statuses and the respondents' perception. In this case, the criterion of one hour worked in the reference week, as used in the "objective" approach, could be the decisive factor. Quite obviously that assumption is contrary to common sense. If the purpose of employment is to earn a living, then (with a few exceptions) it is unrealistic to pursue that objective by working only one hour a week. From that perspective, it would be more appropriate to use no less than two or three full days of work a week. Thus, casual and part-time workers may consider their status to be "unemployment" or "inactivity" though being classed as "employed" in accordance with the "official" criteria. This is at least partially corroborated by the observation of the unemployment rates: if "objective" criteria are applied, weighted and non-weighted data provides similar results in all groups (except for rural areas); whereas the calculations based on the LFS respondents'

\footnotetext{
${ }^{5}$ The author believes this to be acceptable if the study is intended to capture the importance of a phenomenon for economic processes rather than to measure it accurately. Each analysis of economic statistical data should be grounded in economic theory, and should start with a good understanding of the nature and context of processes surveyed. The figures and sophisticated analytical methods are essential, however even if fully satisfied that the methods are adequately selected and employed, the researchers should always be able to see a broader context and cannot narrow their perception of economic processes to the aspect under consideration.
} 
subjective assessment result in considerably higher levels. Similarly, in all the groups surveyed (except for women), labour force participation rates were higher when based on weighted data and "official" criteria. Also noticeable are the extremely large differences between unemployment rates calculated based on weighted and non-weighted data, and between the results based on "official" and "subjective" criteria (Table 1). While the first one could be explained, just like above, by the imperfection of the non-weighted data, the differences between the "official" and "subjective" classification may be due to the perceived inefficiency of one's work. This is probably especially true for the farming population referred to as "family helpers," and for the rural population (whether landowners or landless) engaged in seasonal work in the fields (usually not registered). As regards the rural population, the differences between the results based on "objective" and "subjective" approaches are an indirect indication of yet another problem characteristic of the Polish rural and farming population: the hidden unemployment. This means excessive, economically unviable and technologically unreasonable employment in individual farms. As estimated by Kołodziejczak [2016], excess employment in the Polish agriculture was as high as one million people in 2015 , i.e. ca. $57 \%$ of the sector's total labour force. Therefore, the inefficiently employed farming population may consider their status to be "unemployment" even if they work several days a week because their work is not economically viable and does not provide them with satisfactory incomes (or does not provide any measurable income at all). Similarly, seasonal farm workers could not identify themselves as "employed" because they are not in stable employment and they are not party to an employment contract. Even if they worked for more than one hour during the reference week, they will consider it to be a transitory and temporary situation (just like the casual non-agricultural workers mentioned earlier in this paper). The analysis of the equilibrium unemployment rate may enable a better understanding of the importance of the criteria used to identify the labour market status for the results of this study and for their practical applications. Individual data needs to be used to calculate the indicator based on flows to/from employment, unemployment and inactivity. However, the associated weights are not used because otherwise it would be impossible to disaggregate the population by its demographic and social characteristics (the weights were selected for another composition of the sample). In the reference year, the equilibrium unemployment rate estimated based on "objective" data was $11.3 \%$, i.e. from 1.7 to nearly twice higher than the real unemployment rate calculated with and without the use of weights. Assuming that the equilibrium unemployment rate is a rough approximation of the structural unemployment level [Socha, Sztanderska 2002], the real unemployment would be of a purely structural nature. If the equilibrium unemployment rate is higher than real unemployment, it also suggests there are some factors which (despite the qualitative mismatch in the labour market) enable maintaining a relatively high level of employment (e.g. state intervention, labour market schemes or the shortage of labour force caused by migrations and population 
Table 1. Selected characteristics of the Polish population's economic activity in 2016 (average annual values)

\begin{tabular}{|c|c|c|c|c|c|c|c|c|}
\hline $\begin{array}{c}\text { Criteria } \\
\text { for the } \\
\text { identification } \\
\text { of the labour } \\
\text { market status }\end{array}$ & $\begin{array}{c}\text { Unemployment } \\
\text { outflow rate } \\
(\%)\end{array}$ & $\begin{array}{l}\text { Unemployment- } \\
\text { to-employment } \\
\text { flow rate } \\
(\%)\end{array}$ & $\begin{array}{l}\text { Unemployment } \\
\text { inflow rate }(\%)\end{array}$ & $\begin{array}{c}\text { Average } \\
\text { duration of } \\
\text { unemployment }\end{array}$ & $\begin{array}{c}\text { Employment } \\
\text { rate } \\
(\%)\end{array}$ & $\begin{array}{c}\text { Economic } \\
\text { activity } \\
\text { rate } \\
(\%)\end{array}$ & $\begin{array}{c}\text { Unemployment } \\
\text { rate } \\
(\%)\end{array}$ & $\begin{array}{l}\text { Equilibrium } \\
\text { unemployment } \\
\text { rate } \\
(\%)\end{array}$ \\
\hline \multicolumn{9}{|c|}{ POLAND (TOTAL) } \\
\hline Weighted & . & . & . & 2.8 & 52.8 & 56.2 & 6.2 & . \\
\hline Subjective & 5.7 & 26.6 & 2.9 & 3.2 & 46.9 & 51.8 & 9.5 & 7.8 \\
\hline \multicolumn{9}{|c|}{ MEN } \\
\hline Weighted & . & . & . & . & 60.9 & 64.8 & 6.1 & . \\
\hline Objective & 2.1 & 9.8 & 2.4 & 2.8 & 55.4 & 59.1 & 6.2 & 10.8 \\
\hline Subjective & 4.4 & 28.0 & 2.7 & 3.3 & 54.5 & 60.1 & 9.3 & 7.8 \\
\hline \multicolumn{9}{|c|}{ WOMEN } \\
\hline Objective & 2.2 & 9.9 & 2.7 & 2.4 & 44.3 & 55.7 & 6.1 & 11.8 \\
\hline Subjective & 7.1 & 25.1 & 3.0 & 3.1 & 40.4 & 44.7 & 9.7 & 7.8 \\
\hline \multicolumn{9}{|c|}{ URBAN AREAS } \\
\hline Weighted & . & . & . & . & 53.4 & 56.3 & 5.1 & . \\
\hline Objective & 2.1 & 11.1 & 2.7 & 2.5 & 48.0 & 51.1 & 6.1 & 12.0 \\
\hline Subjective & 6.0 & 27.8 & 2.7 & 3.1 & 47.1 & 51.6 & 8.8 & 7.1 \\
\hline \multicolumn{9}{|c|}{ RURAL AREAS } \\
\hline Weighted &. & . & . & . & 52.9 & 56.4 & 3.5 & . \\
\hline Objective & 2.3 & 8.1 & 2.3 & 2.7 & 48.0 & 51.2 & 6.1 & 10.1 \\
\hline Subjective & 5.2 & 25.2 & 3.0 & 3.4 & 46.5 & 52.0 & 10.5 & 8.7 \\
\hline
\end{tabular}

Source: [Economic activity of the Polish population... 2016], own calculations based on individual non-weighted quarterly data from the 2016 LFS. 
ageing). This could also mean that in the near future, the condition of the labour market is likely to deteriorate, especially if one of the factors responsible for keeping the employment above the equilibrium level becomes ineffective (the real unemployment rates follow the equilibrium unemployment rates). A look at the flow rates enables a better understanding of the above relationships. While making it easier to estimate the equilibrium unemployment level, flow rates carry information on the structural or cyclical nature of unemployment.

In the "subjective" classification, equilibrium unemployment rates were below the real unemployment rates in all groups (Table 1). The difference between equilibrium and real unemployment may be roughly equated to cyclical unemployment, also referred to as Keynesian unemployment. Therefore, if positive, that difference reflects the existence of a certain reserve which makes it possible to reduce unemployment as the market for goods and services recovers and as the economy grows. The flow rates were higher in the "subjective" approach for all population groups surveyed and for all indicators. This means the cyclical factors played a more important role than in the "objective" approach. At the same time, the employment outflow rate and the unemployment-to-employment rate varied strongly depending on the approach used. As regards the rate of inflow to unemployment, both approaches provided similar or equal results. It can be assumed that higher employment outflow rates calculated based on "subjective" data were caused by a greater variability in the changes to individuals' statuses than in the case of the "objective" criterion (once again, note the questionable justification for using the "one hour worked" as an employment criterion). Meanwhile, high unemployment-to-employment flow rates suggest the situation on the labour market is improving (however, a time-series analysis would be required to provide a full picture).

\section{Conclusion}

The example used in this paper shows that different data collection approaches used in the analysis may provide considerably different results. The following conclusions can be made:

1. While the use of weighted data in the calculations is methodologically more sound, non-weighted data is required in order to decompose the population surveyed by socio-demographic characteristics and to track the evolution of labour market statuses. However, to ensure the comparability of results, it is also necessary to rely on non-weighted data across the entire population for which the use of weights would be reasonable. In such cases, the results obtained with the use of non-weighted data should be compared (where possible) to those based on weighted data.

2. The estimated indicator values based on "objective" criteria differ significantly from those based on "subjective" criteria. In the "objective" approach, the criteria used to classify the individuals as "employed" are too liberal. Conversely, in the "subjective" approach, the results are biased by psychological, social and other 
factors. Therefore both approaches should be used jointly, and attempts should be made to explain the differences between the respective results.

3. Each of the analytic approaches provides a different picture of the labour market. The unemployment figures themselves, as estimated for each of the identification methods referred to above, provide valuable insights. Additionally, an investigation of the reasons behind the differences in the results provided by the two approaches could become a source of important guidelines for decision-making processes regarding economic policy and labour market policy.

4. It is particularly important to properly identify the problem areas to be addressed by the relevant measures, and to determine, at least approximately, the importance of the cyclical and structural factors for unemployment and employment levels. To that extent, the results differ depending on whether "objective" or "subjective" criteria are used; this could lead to the formulation of divergent recommendations. To identify the ones closer to the reality, other parameters related to changes in labour force statuses (especially the flow rates) need to be analysed and monitored as time series data. However, first of all, the analysis must be grounded in economic theory and conducted in a reference system which takes economic and demographic as well as social and political variables into consideration.

\section{Bibliography}

Darby M., Haltiwanger J., Plant M., 1986, Unemployment Rate Dynamics and Persistent Unemployment under Rational Expectations, American Economic Review, 75(4).

Economic Activity of the Polish Population 4Q 2016, 2016, GUS, Warszawa.

European Union Labour Force Survey Methods and Definitions 2001, 2003, Office for Official Publications of the European Communities, Luxembourg.

Gärtner M., 1997, A Primer in European Macroeconomics, Prentice Hall, London.

http://ec.europa.eu/eurostat/statistics-explained/index.php/EU_labour_force_survey_-_methodology (28.03.2018).

http://ec.europa.eu/eurostat/web/lfs/methodology/main-concepts (28.03.2018).

Individual non-weighted quarterly data from the 2016 LFS (BAEL).

Kabaj M., 2003, Mechanizmy tworzenia i likwidacji miejsc pracy w polskiej gospodarce. Jak utworzyć 2 miliony nowych miejsc pracy do 2010 r., Materiał z posiedzenia Rady Społeczno-Gospodarczej, Warszawa.

Kołodziejczak W., 2016, Hidden unemployment in Polish agriculture in 1995-2015, Journal of Agribusiness and Rural Development, 4(42).

Kołodziejczak W., Wysocki F., 2007, Bezrobocie równowagi i bezrobocie rzeczywiste w Polsce i na wsi w latach 1992-2004, Wieś i Rolnictwo, 1.

Kołodziejczak W., Wysocki F., 2013, Identyfikacja charakteru bezrobocia w Polsce w latach 2006-2009, Gospodarka Narodowa, 9(265).

Kołodziejczak W., Wysocki F., 2015, Determinanty aktywności ekonomicznej ludności wiejskiej w Polsce, Wydawnictwo Uniwersytetu Przyrodniczego w Poznaniu, Poznań.

Kwiatkowski E., 2002, Bezrobocie. Podstawy teoretyczne, Wydawnictwo Naukowe PWN, Warszawa, Mankiw N.G., Taylor M.P., 2009. Makroekonomia, Wydawnictwo Naukowe PWN, Warszawa.

Masterson Ch., 2011, The Crash Course: The Unsustainable Future of Our Economy, Energy, and Environment, John Wiley \& Sons, Inc., Hoboken, New Jersey. 
Socha M., Sztanderska U., 2002, Strukturalne podstawy bezrobocia w Polsce, Wydawnictwo Naukowe PWN, Warszawa.

Socha M., Wojciechowski W., 2004, Koncepcja NAIRU dezinflacja a druga fala bezrobocia w Polsce, Bank i Kredyt, 35(3).

Unemployment: Choices for Europe, 1995, The Centre for Economic Policy Research (CEPR), London.

\section{KRYTERIA IDENTYFIKACJI STANU AKTYWNOŚCI EKONOMICZNEJ LUDNOŚCI STOSOWANE W BADANIACH BAEL VERSUS SUBIEKTYWNA OCENA RESPONDENTÓW - IMPLIKACJE DLA BADAŃ BEZROBOCIA}

Streszczenie: W Badaniu Aktywności Ekonomicznej Ludności (BAEL) poszczególne ankietowane osoby zalicza się do pracujących, bezrobotnych lub biernych zawodowo na podstawie „obiektywnych” kryteriów ustalonych w założeniach metodycznych. Takie podejście umożliwia oddzielenie klasyfikacji od subiektywnych odczuć respondentów i jest stosowane od 1992 roku. Począwszy od roku 2006, respondenci BAEL mogą także samodzielnie identyfikować swój stan aktywności ekonomicznej. Celem artykułu było wskazanie i próba wyjaśnienia różnic występujących między wynikami uzyskanymi na podstawie identyfikacji stanów aktywności ekonomicznej przeprowadzonej zgodnie z kryteriami GUS i samodzielną klasyfikacją dokonywaną przez poszczególnych respondentów BAEL. Rozważono zasadność stosowania każdego z badanych podejść i implikacje ich wyboru dla przebiegu i wyników badania zjawiska bezrobocia w ujęciu statycznym i dynamicznym.

Słowa kluczowe: BAEL, bezrobocie, aktywność zawodowa, metoda przepływów na rynku pracy. 